\title{
A REVIEW ON LOWER APPENDICULAR MUSCULOSKELETAL SYSTEM OF HUMAN BODY
}

\author{
M. Akhtaruzzaman*, A. A. Shafie, AND M. R. KHAN \\ Department of Mechatronics Engineering, Faculty of Engineering, \\ International Islamic University Malaysia, 53100 Kuala Lumpur, Malaysia. \\ *akhter900@gmail.com,aashafie@iium.edu.my, and raisuddin@iium.edu.my \\ (Received: 20 Jul. 2015; Accepted: 24 Dec. 2015; Published on-line: 30 Apr. 2016)
}

\begin{abstract}
Rehabilitation engineering plays an important role in designing various autonomous robots to provide better therapeutic exercise to disabled patients. Hence it is necessary to study human musculoskeletal system and also needs to be presented in scientific manner in order to describe and analyze the biomechanics of human body motion. This review focuses on lower appendicular musculoskeletal structure of human body to represent joints and links architectures; to identify muscle attachments and functions; and to illustrate muscle groups which are responsible for a particular joint movement. Firstly, human lower skeletal structure, linking systems, joint mechanisms, and their functions are described with a conceptual representation of joint architecture of human skeleton. This section also represents joints and limbs by comparing with mechanical systems. Characteristics of ligaments and their functions to construct skeletal joints are also discussed briefly in this part. Secondly, the study focuses on muscular system of human lower limbs where muscle structure, functions, roles in moving endoskeleton structure, and supporting mechanisms are presented ellaborately. Thirdly, muscle groups are tabulated based on functions that provide mobility to different joints of lower limbs. Finally, for a particular movement action of lower extremity, muscles are also grouped and tabulated to have a better understanding on functions of individual muscle. Basically the study presents an overview of the structure of human lower limbs by characterizing and classifying skeletal and muscular systems.
\end{abstract}

ABSTRAK: Kejuruteraan pemulihan memainkan peranan yang penting dalam mereka bentuk pelbagai robot autonomi untuk menyediakan latihan terapeutik yang lebih baik untuk melumpuhkan pesakit. Jadi, ia adalah perlu untuk mengkaji sistem otot manusia dan perlu disampaikan secara saintifik untuk menerangkan, dan menganalisis biomekanik gerakan tubuh manusia. Kajian ini memberi tumpuan kepada struktur otot appendicular bawah badan manusia untuk mewakili sendi dan menghubungkan seni bina; mengenal pasti lampiran otot dan fungsi; dan menggambarkan kumpulan otot yang bertanggungjawab untuk pergerakan sendi tertentu. Pertama, struktur rangka yang lebih rendah manusia, sistem yang menghubungkan, mekanisme sendi dan fungsi mereka adalah seperti yang dinyatakan dengan perwakilan konsep seni bina bersama rangka. Seksyen ini juga mewakili sendi dan anggota badan dengan membandingkan dengan sistem mekanikal. Ciri-ciri daripada ligamen dan fungsi mereka untuk membina sendi tulang juga dibincangkan secara ringkas di bahagian ini. Kedua, kajian memberi tumpuan kepada sistem otot anggota badan manusia yang lebih rendah. Struktur otot, fungsi, peranan dalam menggerakkan struktur rangka dalam, dan menyokong mekanisme yang dibentangkan di dalam bahagian ini. Ketiga, kumpulan otot adalah jadual berdasarkan fungsi yang menyediakan mobiliti kepada sendi yang berbeza anggota badan yang lebih rendah. Akhir sekali, untuk tindakan gerakan tertentu hujung yang lebih rendah, otot juga dikumpulkan dan dijadualkan untuk mempunyai pemahaman yang lebih baik mengenai fungsi otot 
individu. Pada asasnya kajian mewakili gambaran keseluruhan struktur anggota bawah manusia dengan mencirikan dan mengelaskan sistem rangka dan otot.

KEYWORDS: Musculoskeletal system; Human lower limbs; Muscle groups; Joint motion; Biomechatronics; Rehabilitation.

\section{INTRODUCTION}

Stroke is one of the major causes for morbidity and disability, both in the developed and developing countries [1]. It is a common neurological disorder that causes post-stroke depression among survivors. Many survivors suffer from physical and psychological disabilities. One study presents that $66 \%$ of 80 stroke patients were in post-stroke depression where $51 \%$ were in mild, $11 \%$ were in moderate and $4 \%$ were in severe condition [2]. About 15 million people globally suffer from stroke where 5 million people die and 5 million become permanently disabled [3,4]. Neurological impairment of post-stroke patient often conducts to hemiparesis (partial paralysis of one side of body). Hemiparesis can lead to profoundly impaired functional performance of daily activities such as running, walking, standing, speaking, and eating. It is observed that, at 6 months of post-stroke, about $50 \%$ of survivors get hemiplegia, $30 \%$ are unable to walk and $26 \%$ become dependent for their daily activities [5].

Nowadays robot assisted therapy is increasingly attractive in stroke rehabilitation both for upper and lower limbs of human body $[6,7]$. Robotic systems unfold a wide range of opportunities to study on functional adaptation of various limbs of post-stroke patients [810]. Robotic tools also provide opportunity to observe and measure improvements of functionality of a particular muscle as well as limbs [11-14]. Robot assisted therapy for lower limbs shows successful improvements in functional limitations of stroke patients with reduction of motor impairments $[5,15]$. Basically, robotic skeletal arm provides external force to perform limb motions of lower extremity so that muscle and joint system mobility remains active. This therapeutic exercise also improves the nervous system of human lower limbs. The activity can be represented in a block diagram as presented in Fig. 1.

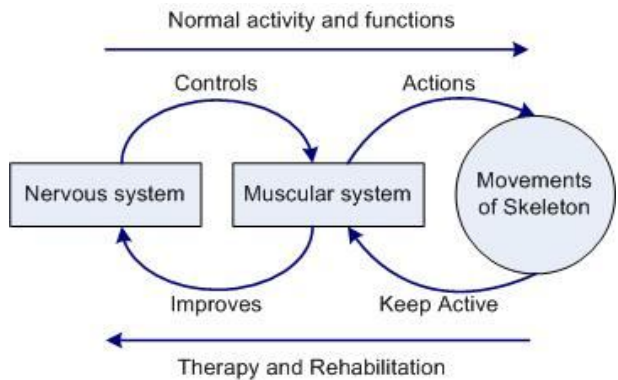

Fig. 1: Block diagram of musculoskeletal system activity process versus rehabilitation.

It is very important to keep in mind that simply movement (passive exercise) of impaired limbs do not provide maximum recovery level for a stroke patient. Recognition of cortical functionalities, feedback control, and learning of motors are also involved in intense use of impaired limbs. Studies on the response of complex biological systems, in terms of its mechanics and electronics, is the focus of biomechatronics engineering. Therefore, understanding musculoskeletal structure of biological systems especially the human body 
becomes very important in biomechatronics engineering research. In this review, only musculoskeletal structure of human lower extremity is studied to present endoskeletal joint structures, muscle attachments, muscle groups, and muscle functionalities of a particular movement of lower limbs. Studies on biomechanics and biomechatronics of musculoskeletal system provides better understanding of joint movements, trajectories, joint functions, and dynamic properties of biological systems [16]. Appropriate design of various mechanical and robotic systems such as artificial joint, orthotic devices, medical therapeutic devices, robot assisted system, exoskeleton etc. are also required for a proper analysis and understanding of musculoskeletal systems [17] and functions of biological systems so that any secondary injury can be avoided.

\section{SKELETAL SYSTEM OF HUMAN LOWER LIMBS}

The human musculoskeletal system has a primary responsibility to interact with physical environment to produce normal movement. Balancing body and normal locomotion, especially walking, are ensured by proper functioning musculoskeletal structure of the lower limbs of human body. The lower limbs also support superior parts of a body such as neck, head, and torso. Basically, human body is the accumulation of a number of independent systems. Holding structure and balancing body movements are controlled by nervous system, vascular system, skeletal system, muscular system, ligaments, and tendons [18]. For the purpose of lower limbs rehabilitation, it is important to understand the functions of lower torso of human body as well as functions of independent systems of musculoskeletal structure. Study on functions of lower extremity not only focuses on a single joint movement, but also refers to the structure and behavior of limbs, pelvis, and trunk [18]. Figure 2 presents structure of human endoskeletal system.

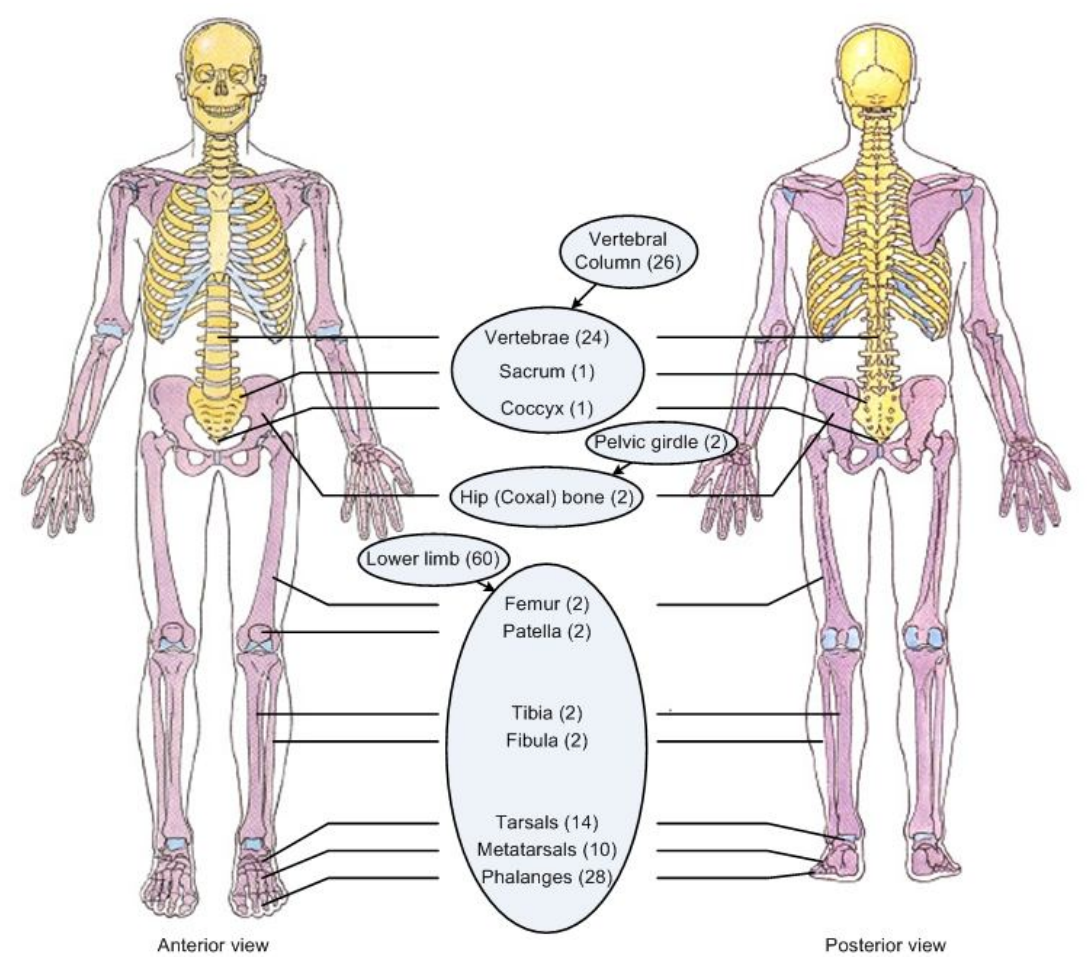

Fig. 2: Anterior and posterior view of human endoskeletal structure focusing on the lower extremity of the system [22]. 
Human body musculoskeletal structure is formed based on endoskeleton of human body that consists of rigid bones. Skeletal system not only provides structural support but also ensures protection, functions as levers, works as storage (of minerals and fats), and helps in blood cell formation [18]. Lower extremity of human skeletal system consists of pelvic girdle segment, thigh (proximal segment), shank (distal segment/lower leg), and foot. Connection portions of segments are called joints. Most of the joints of lower limbs are synovial joints (joint so articulated as to move freely) with cavities that contain synovial fluid $[18,19]$. All of these joints are almost frictionless $(\mathrm{Fr} \approx 0)$ comparing to any other systems in the World and are also highly efficient shock absorbers [19]. Hip, knee, and ankle are the largest articulated joints of lower extremity of human endoskeleton. These joints are holding segments (bones) in place through a system of cartilage, tendons, and ligaments [18-20]. Figure 3 shows a conceptual architecture of the joints of human musculo-skeletal system.

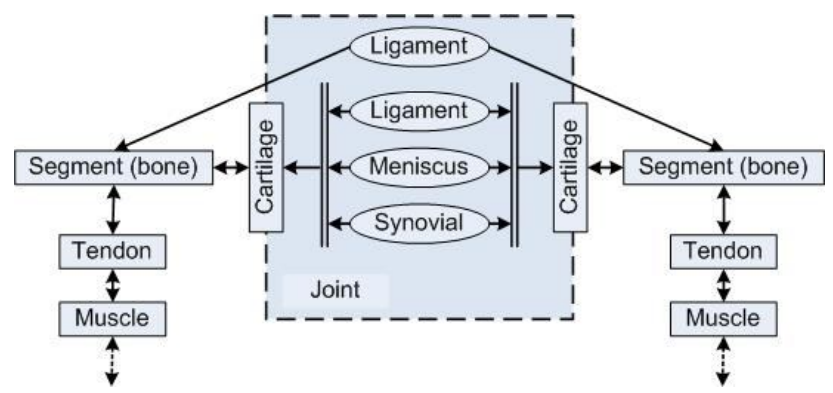

Fig. 3: Basic and conceptual architecture of joint in human musculoskeletal system.

\subsection{Pelvis Girdle}

Between torso and lower limbs, pelvic girdle plays an important role as a crucial linking system that acts as a fulcrum in between actions of upper and lower extremities $[18,19]$. Movement of one leg is counter balanced by other leg through the anatomical structure of pelvic. Hip joint mechanism of musculoskeletal system is structurally supported by the pelvic girdle [20,21]. Pelvis is formed by three bones; Ilium, Ischium, and pubic symphysis [21,22] as shown in Fig. 4(a). Pubic symphysis is a kind of cartilaginous joint. This type of joint has slight movement capability which separates articulating surface of contingent bones [22]. This type of joint exists between bodies of vertebrae and also in structure of ribcage. Slight movement capability of joint allows pelvic girdle work as a suspension system while walking, running, and jumping especially on uneven surface.

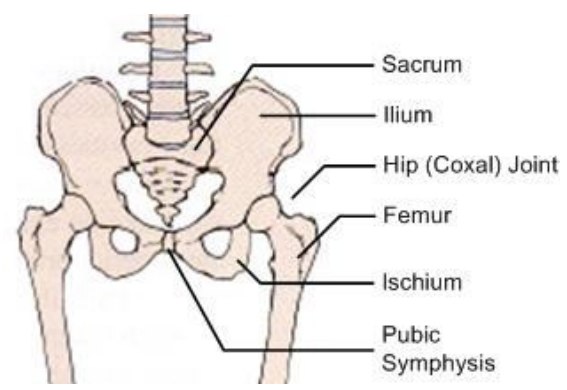

(a)

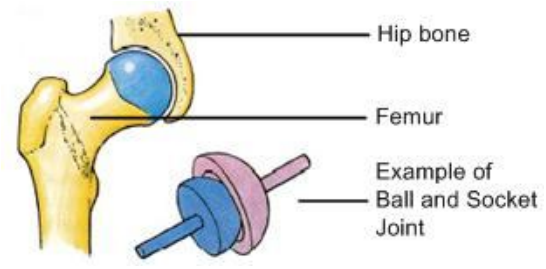

(b)

Fig. 4: Pelvic girdle and hip (coxal) joint structure [22], (a) Skeleton of pelvis, and

(b) Hip joint structure (synovial joint). 


\subsection{Hip Joint (Coxal Joint)}

Joint that is formed at the meeting point of femur head and hip's acetabulum socket is a perfect example of ball and socket joint as presented in Fig. 4(b). This is a type of synovial joint (diarthrotic joint) that allows triaxial movement of lower limbs. Synovial joints are the most mobile comparing to all other joints in human skeleton [22]. Triaxial movement of lower limbs can be characterized as flexion, extension, abduction, adduction, medial rotation, lateral rotation, and circumduction. Figure 5 shows the ligaments of pelvis and hip structure of human endoskeleton.

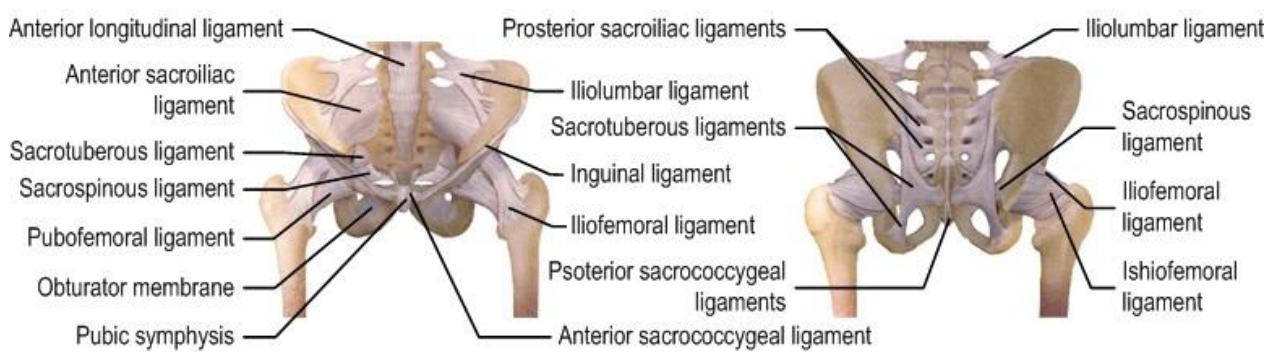

(a)

Fig. 5: Ligaments of pelvis and hip of human skeletal system [23], (a) Anterior view of pelvis and hip, (b) Posterior view of pelvis and hip.

\subsection{Knee Joint (Tibiofemoral Joint)}

Lower portion of femur and upper side of tibia (shin bone) are connected together with multiple ligaments at knee joint. There is a small bone at the anterior portion of knee joint which is called as patella. These three bones form the synovial joint (diarthrotic joint) for knee which is an example of a hinge joint with ellipsoidal shape allowing roll and glide movement capability $[18,19,22]$. Patella has sliding movement capability on femoral groove as it is connected with tibia through Patella tendon at the bottom side and with quadriceps muscles through quadriceps tendon on the upper side [23]. Articular cartilage at the surface of opposing bones provides principal interface of articulation [25].

Multiple ligaments at knee ensure stability of the joint [24]. Furthermore, lateral and medial meniscus (have loose peripheral attachment to the joint capsule) of knee joint provide extra structural support. Studies show that meniscus has about 50\% of intrinsic elastic modulus and $10 \%$ to $16 \%$ of permeability of articular cartilage [19]. So, compressive viscoelastic creep behavior of meniscus is regulated, to a great extent, by interstitial fluid that flows through tissue during compression. Two characteristics, low compressive stiffness and low permeability, of menisci prove that the system is able to function as a robust and efficient shock absorber. Most of the mechanical shocks are generated at knee joint and absorbed by meniscus. Total mass of menisci is much greater than articular cartilage-bearing load across knee joint (femoromeniscotibial articulation) [19]. Deformable characteristic of menisci with low compressive, shear stiffness, and permeability ensures well distribution of load at knee joint.

Tibiofemoral joint (knee joint) allows one degree of freedom (DoF) of movement which can be characterized as flexion and extension [22]. Knee joint also allows a slight medial and lateral rotation which characterize the joint as biaxial (2 DoF) [18]. Figure 6 presents knee joint motions and example of hinge joint resembling tibiofemoral joint. Ligaments involved to stable tibiofemoral joint are presented in Fig. 7. 


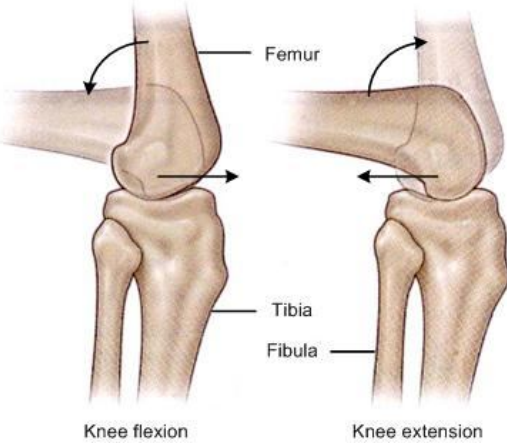

(a)

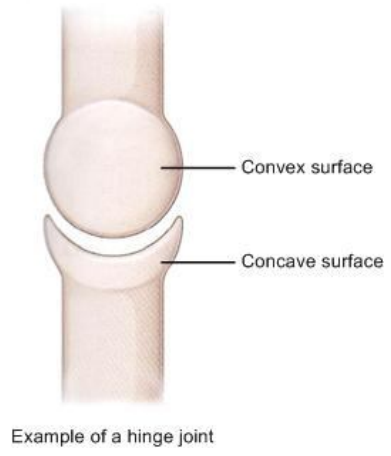

(b)

Fig. 6: Tibiofemoral joint (knee joint) structure and movements [22], (a) Lateral view of tibiofemoral joint representing roll and glide of tibiofemoral joint while flexion and extension, (b) Convex-concave surface of a hinge joint that follows the convex-concave rule to determine direction of glide and roll movement.

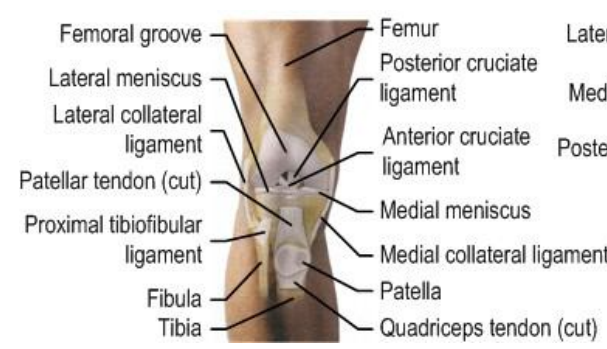

(a)

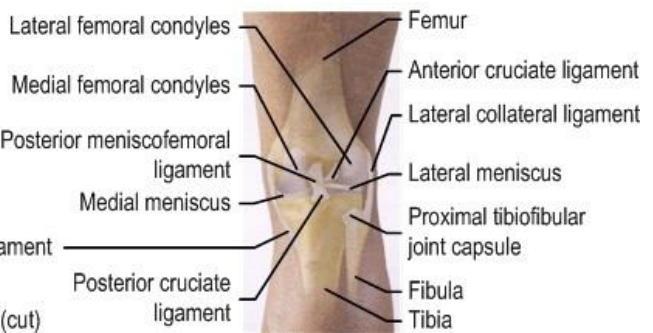

(b)

Fig. 7: Ligaments of tibiofemoral joint [23], (a) Anterior and (b) Posterior view of right knee joint.

\subsection{Leg (Syndesmosis)}

Leg of human skeleton is formed with two bones, tibia and fibula. These two bones are also firmly attached by interosseus membrane and ligaments. This is fibrous type joint called syndesmosis [22]. This type of joint is more stable as bones are connected tightly together and there is a little (or no) movement at this joint. Figure 8 shows skeletal architecture of lower leg and Fig. 9 presents syndesmosis (fibrous joint) between tibia and fibula.

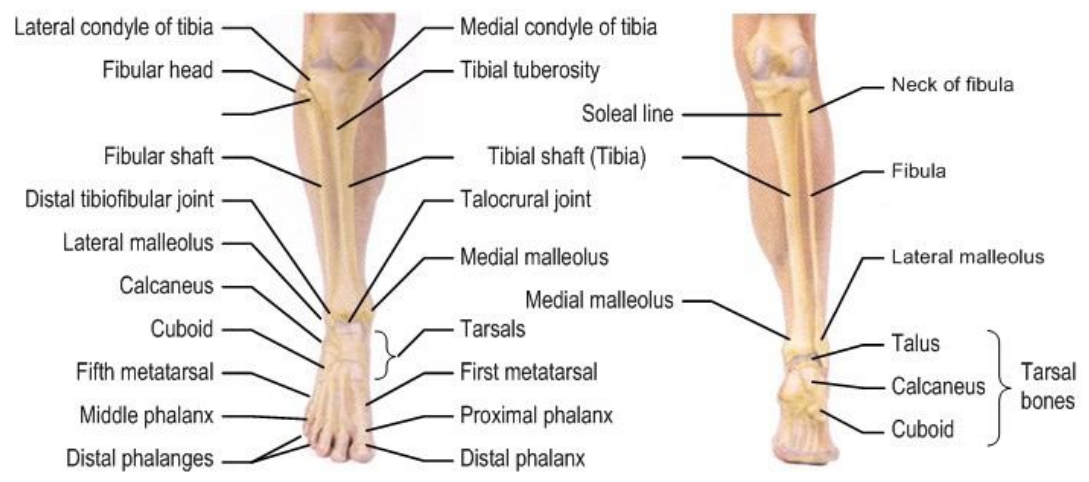

(a) (b)

Fig. 8: Skeletal structure of human leg, ankle, and foot [26], (a) Anterior, and (b) Posterior view. 


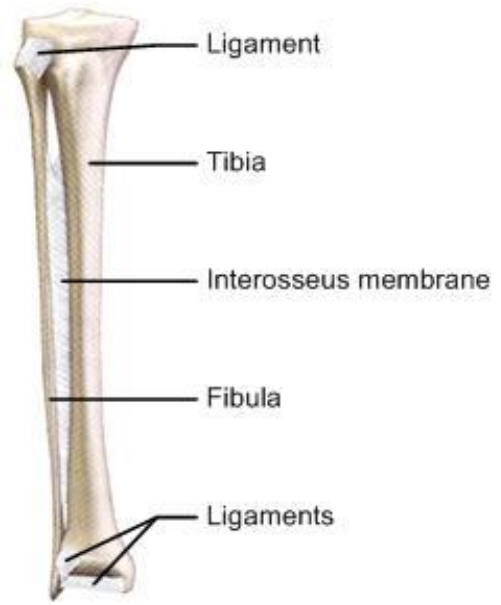

Fig. 9: Syndesmosis (fibrous joint) of leg formed by ligaments and interosseous membrane [22].

\subsection{Ankle Joint (Talocrural Articulation)}

Connection point between lower leg and foot is called ankle joint which also works like a hinge joint. Medial malleolus and lateral malleolus of ankle joint are formed by inferior portion of two bones, tibia and fibula, of leg. Both malleolus of ankle is connected and attached to main ankle-foot tarsal bone called talus. Ankle joint is uniaxial and has only one DoF. Mobility of ankle joint is characterized as planter flexion and dorsiflexion [18,26]. These movement capabilities of ankle hinge joint drive body forward or backward on sagittal plane.

Foot is one of the most mobile structures having complex joint mechanisms that supports body to absorb shock of ground contact force and adapt with various surfaces [26]. Complex multi joint structure has in total of seven tarsal bones which ensure triaxial movement ( $3 \mathrm{DoF}$ ) of a foot. As a result, foot movements are also characterized as inversion and eversion. These tarsal bones are attached to each other such as, Talas with Calcaneus (heel bone), Talas with Navicular, Calcaneus with Cuboid, Calcaneus with Navicular, Navicular with three Cuneiforms (medial, internal and lateral), Navicular with Cuboid, and cuneiform bones with each other. Calcaneus bone of tarsal group supports almost $50 \%$ of total body weight $[18,26]$. Skeletal structure of a foot is presented in Fig. 10.

Tarso-metatarsal joint comprises four tarsal bones (three cuneiforms and cuboid) connected to five metatarsal bones of toes as shown in Fig. 10. First three metatarsal bones are connected with three cuneiform bones accordingly. Fourth metatarsal is connected with both lateral cuneiform and cuboid bones. Finally, lateral metatarsal is solely connected to cuboid tarsal $[18,26]$. First and second metatarsals support about $25 \%$ of total body weight. Rest of the body weight (about 25\%) is absorbed by $3^{\text {rd }}, 4^{\text {th }}$, and $5^{\text {th }}$ metatarsals [18]. Figure 11 to 14 show ligament structure of a foot skeleton. Phalanges of five toes are contacted with five metatarsal bones where each of the phalanges, from $2^{\text {nd }}$ to $5^{\text {th }}$ has three bones (proximal phalanx, middle phalanx, and distal phalanx) and $1^{\text {st }}$ one has two bones, proximal phalanx and distal phalanx, as presented in Fig. 10. Phalange joints are also considered as hinge joints having $1 \mathrm{DoF}$ and movements are characterized as flexion and extension. 


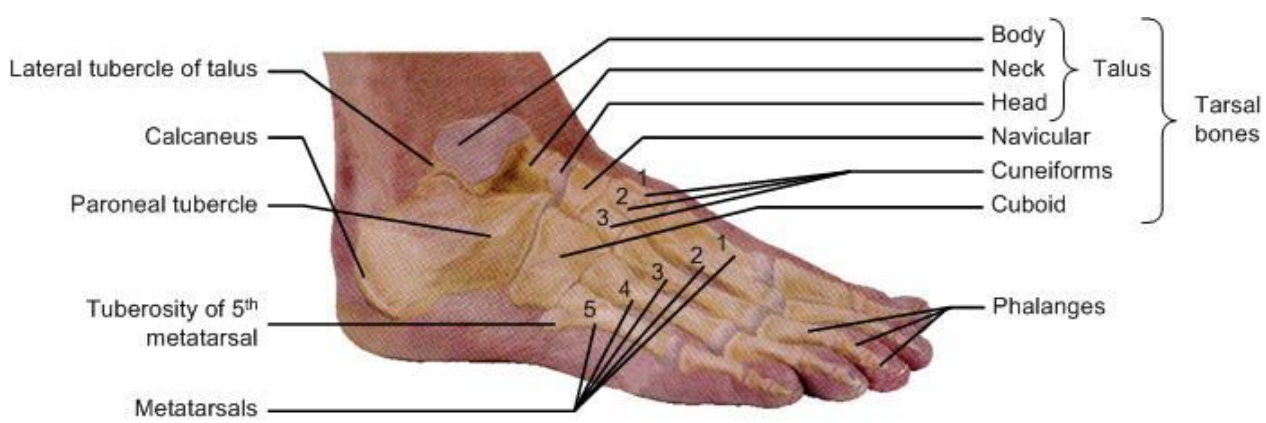

(a)

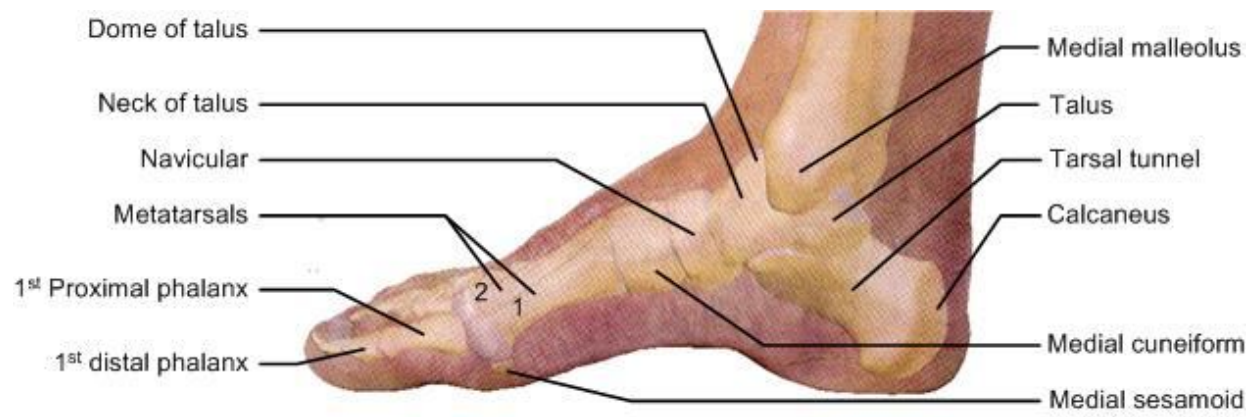

(b)

Fig. 10: Skeletal structure of right foot [26]. (a) Lateral view, and (b) Medial view.

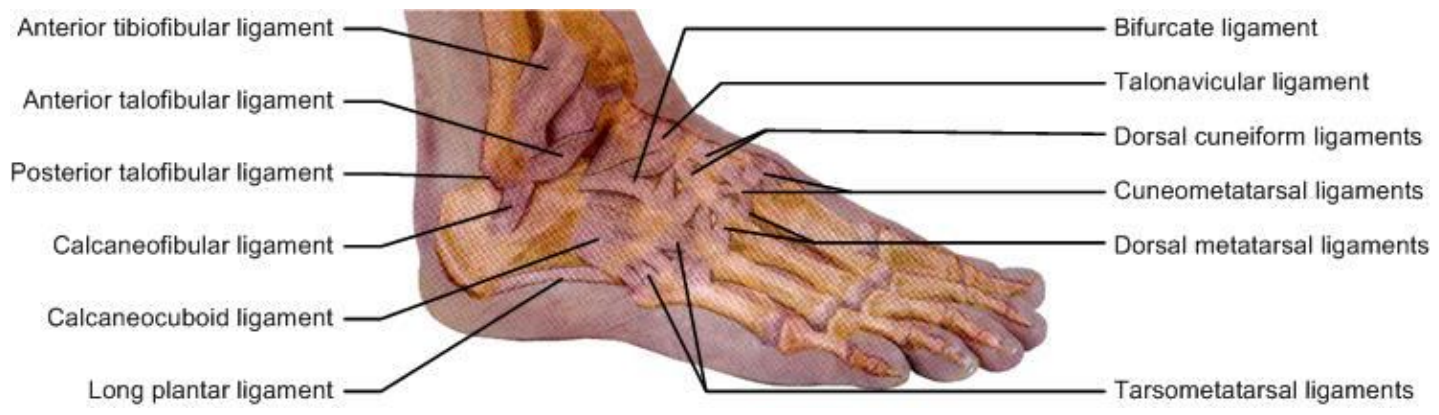

Fig. 11: Ligaments of right foot (lateral view) [26].

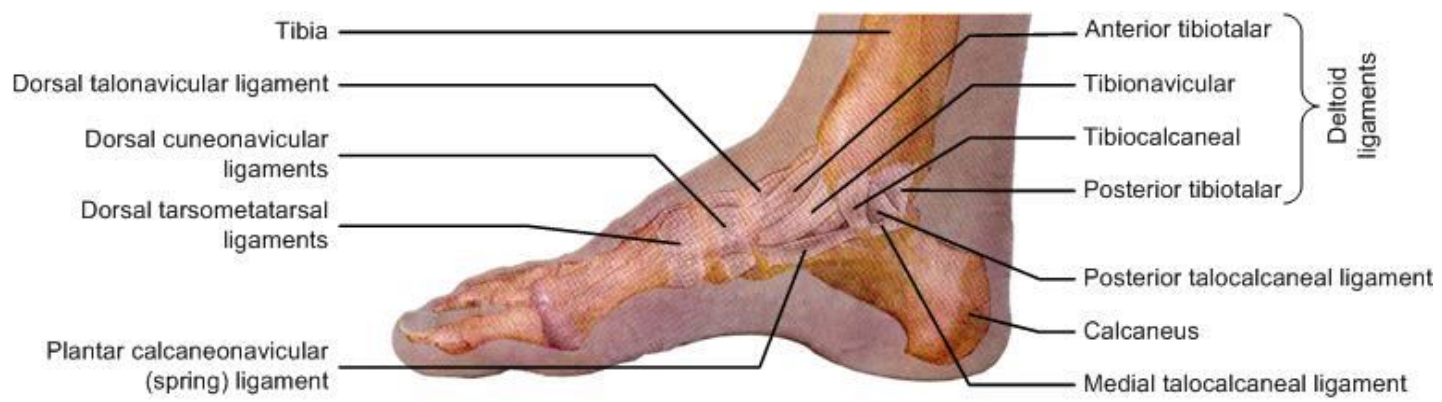

Fig. 12: Ligaments of right foot (medial view) [26]. 


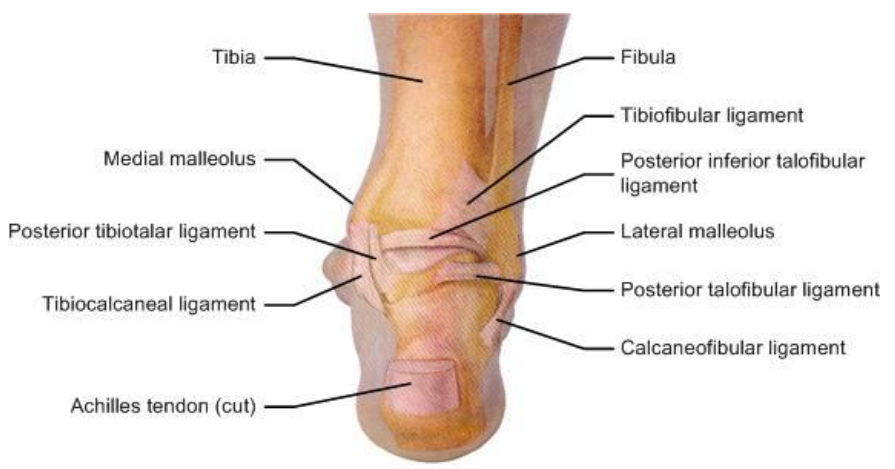

Fig. 13: Ligaments of right foot (posterior view) [26].

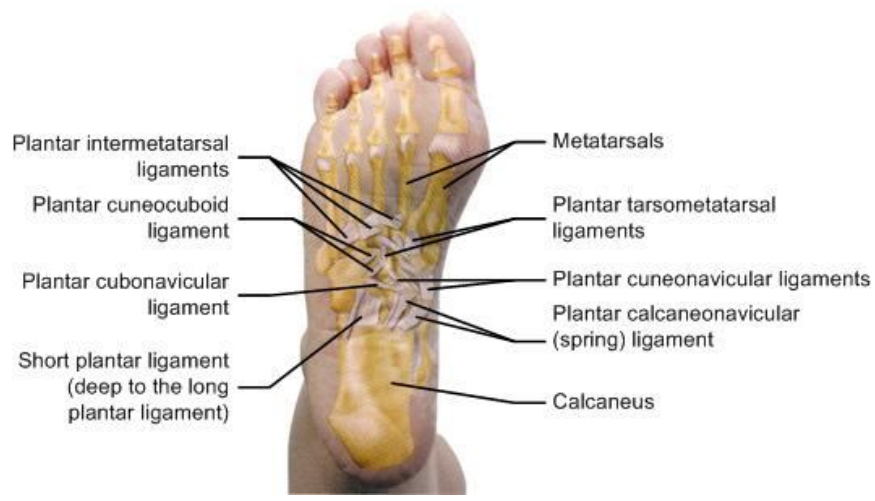

Fig. 14: Ligaments of right foot (inferior view) [26].

\section{MUSCULAR SYSTEM OF HUMAN LOWER LIMBS}

Skeletal muscle plays an important role in protecting endoskeleton against injury, producing joint movements and locomotion. Skeletal muscle forms about $40 \%$ to $45 \%$ of total body weight [21]. Rudimentary structural element of skeletal muscle is muscle fiber, a single cell, which is apparently very long but usually shorter than individual muscle [21]. Each fiber is surrounded by endomysium layer and fibers are bundled together called fascicles. Fascicles are surrounded by perimysium and finally multiple perimysium are layered by epimysium which is tough enough, friction less, and anchors muscle fibers to tendons at both ends of a muscle. Other end of each tendon is attached with endoskeleton. A muscle could be attached with bones through one or more joints [18,21,27]. Figure 15 and 16 present conceptual architecture and anatomy of skeletal muscle respectively.

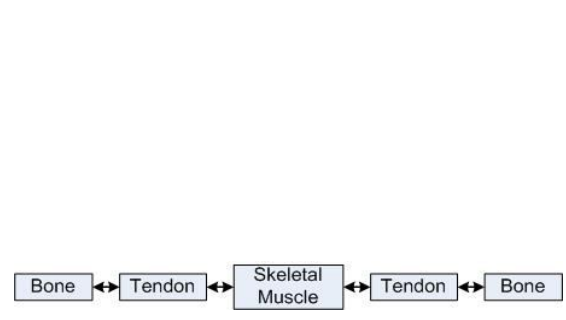

(a)

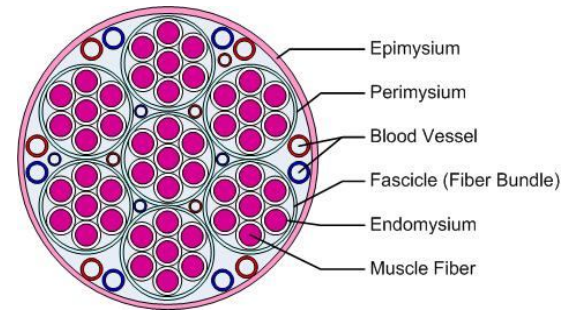

(b)

Fig. 15: Conceptual architecture and connectivity of skeletal muscle, (a) tendon and bone connectivity concept, and (b) cross sectional architecture concept. 


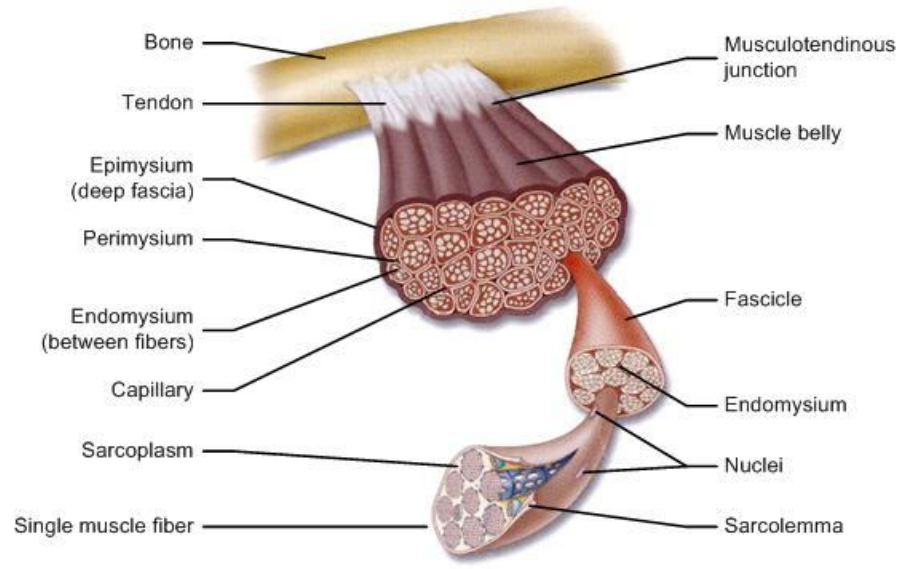

Fig. 16: Basic anatomy of skeletal muscle [27].

Primary uses of skeletal muscles of lower extremity are leverage and locomotion by exerting a pull on bones. During both dynamic activities and static posture, skeletal muscle plays a significant role to stabilize skeletal segments and joint structures [18]. Skeletal muscles, such as abdominal muscle, protect underlying structure and organs of human body. Other two important activities of skeletal muscles are, producing body heat (thermogenesis), and vascular pumping. About $75 \%$ of total energy generated by muscle tissue is heat which keeps the body warm [27]. On the other hand, contraction of skeletal muscle helps to propel fluids of lymphatic vessels and veins having comparatively low pressure than arteries. Basically, skeletal muscle congregates properties of extensibility (stretching without sustaining damage), elasticity (ability to return to its original shape), excitability (ability to response to a stimulus by generating electrical signals), conductivity (ability to propagate electrical signals), and contractility (ability to produce force by shorten or thicken), which ensures unique ability of skeletal muscles.

Endoskeleton is a multi-joint system of rigid bones acting as levers and with the muscle system it produces internal forces to move it. This mechanism is comparable with a composite system of levers [27] where joints act as axes of levers. Common resistances (external opposite force) of muscle force are gravity and friction. There are three types of levers in human musculoskeletal system, (a) First-class lever, (b) Second-class lever, and (c) Third-class lever $[27,28]$. In a first-class lever axis is in between the force and the resistance, can be represented as Force-Axis-Resistance (FAR). This type of lever mechanism is used in skeletal structure for balancing. A second-class lever is ForceResistance-Axis (FRA) type where resistance is in the middle of force and axis. This type of lever mechanism is found at ankle joint when a human being try to stand on the tips of their feet. Second-class lever is very powerful in terms of motion range and speed. Finally, third-class lever mechanism has force in between resistance and axis, reflecting ResistanceForce-Axis (RFA) type. This is the most common type of lever found in human musculoskeletal structure. Knee joint movements are managed by this type of lever mechanism.

Muscles of lower extremity can be grouped depending on various criteria such as, (a) corresponding segments [18], (b) actions or movements [23], (c) innervation [23], (d) corresponding joints [29] etc. Figure 17 and 18 show muscles of the lower musculoskeletal system of a human body. 


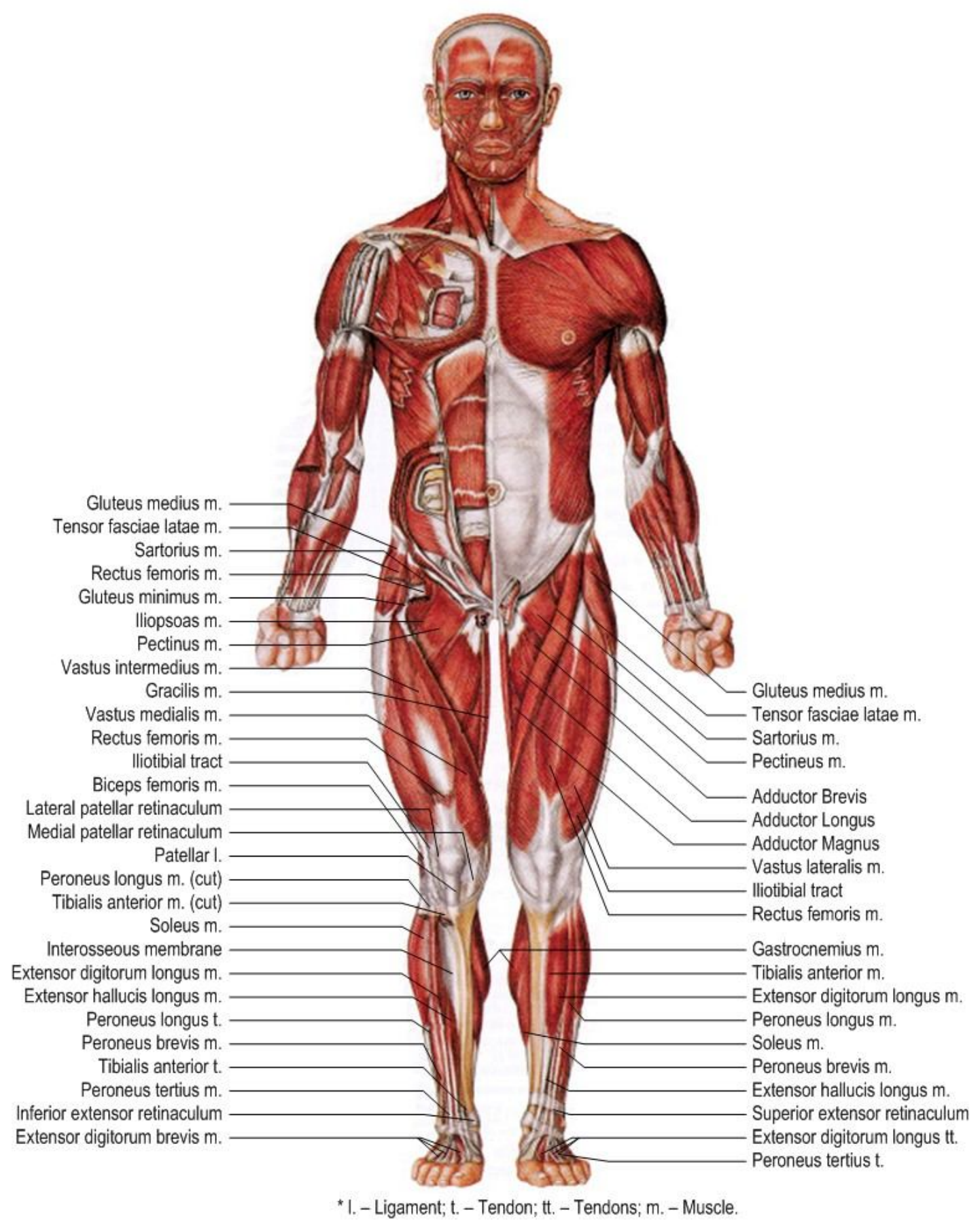

Fig. 17: Muscles of human body lower extremity (Anterior view) [27]. 


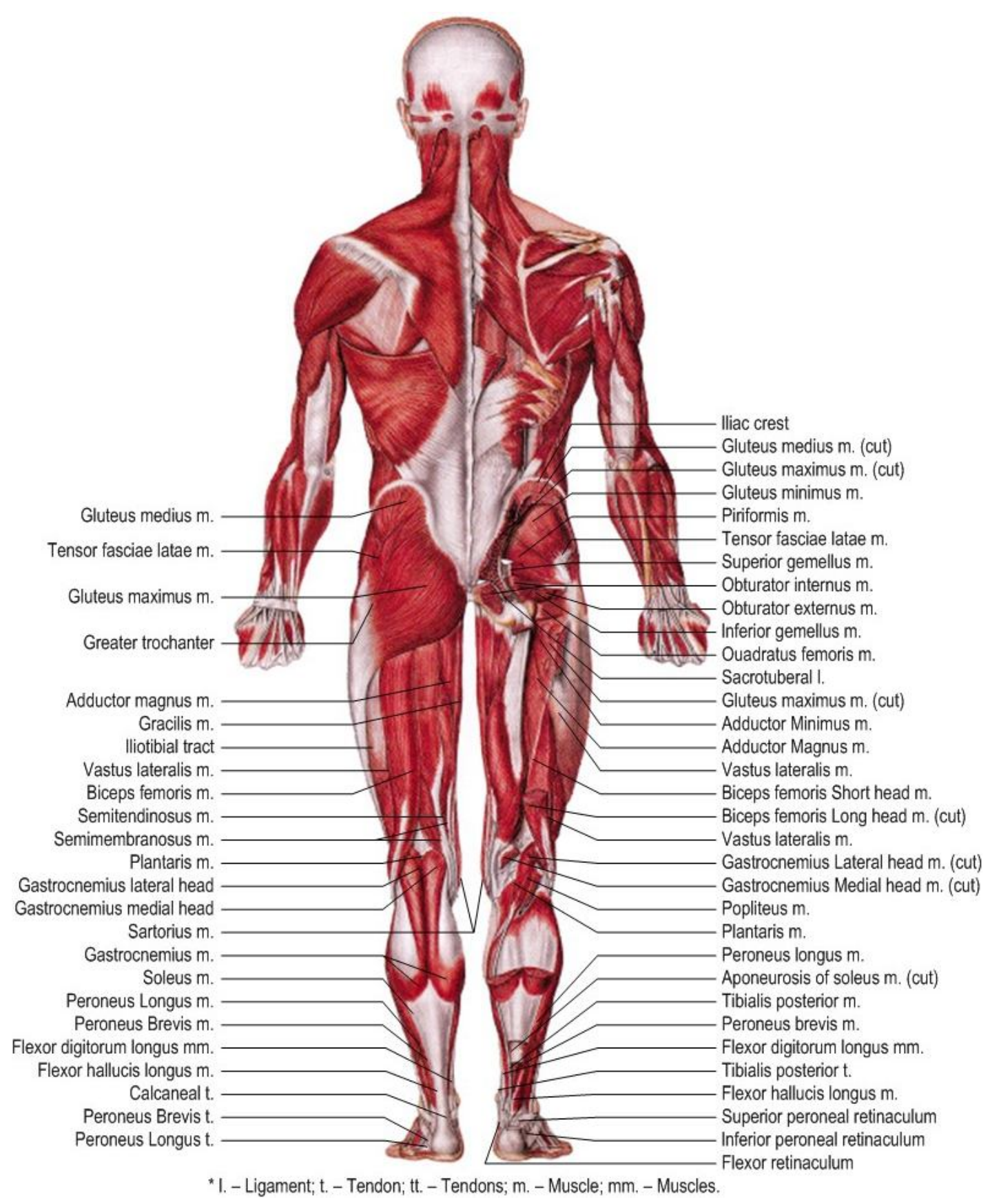

Fig. 18: Muscles of human body lower extremity (Posterior view) [27].

Muscles acting on various joints of the lower extremity of a human body are grouped and characterized based on their functions of particular joint movements, as presented in Table 1, Table 2, and Table 3. Muscles are also characterized based on their attachments, origins (O) and insertions (I), with corresponding bones, and their innervation system. In terms of robotic therapy systems, these significant characteristics are very important to understand the complex system of humanoid lower extremity. 
Table 1: Muscles acting on lower extremity Hip Joint [23,30-32]

\begin{tabular}{|c|c|c|c|c|}
\hline Muscles (Hip joint) & Group & Innervation & Attachments & Functions \\
\hline $\begin{array}{c}\text { Psoas } \\
\text { (Major and Minor) }\end{array}$ & \multirow{2}{*}{ lliopsoas } & \multirow{3}{*}{ Femoral nerve; L2, L3, L4. } & $\begin{array}{l}\text { O: Transverse processes, lateral bodies, and corresponding intevertberal disks of TI2, L1 - L5. } \\
\text { I: Lesser trochanter of femur. }\end{array}$ & \multirow{2}{*}{ Flx., LR.(Asst.) } \\
\hline lliacus & & & O: lliac fossa and ala of sacrum. I: Lesser trochanter of femur. & \\
\hline Rectus Femoris & Quadriceps & & O: Anterior inferior iliac spine (AIIS). I: Tibial tuberosity via patellar tendon. & Flx., Ab.(Asst.) \\
\hline Sartorius & $\begin{array}{l}\text { Anterior } \\
\text { Femoral }\end{array}$ & Femoral nerve; L2, L3. & $\begin{array}{l}\text { O: Anterior superior iliac spine (ASIS). } \\
\text { I: Medial shaft of tibia via pes anserine tendon. }\end{array}$ & Flx., Ab.(Asst.), LR \\
\hline Pectineus & \multirow{5}{*}{ Adductor } & $\begin{array}{l}\text { Femoral and obturator } \\
\text { nerves; L2, L3, L4. }\end{array}$ & $\begin{array}{l}\text { O: Superior ramus of pubis. } \\
\text { I: Pectineal line of femur. }\end{array}$ & Flx., Add. \\
\hline Adductor Brevis & & \multirow{2}{*}{$\begin{array}{l}\text { Obturator nerve; } \\
\text { L2, L3, L4. }\end{array}$} & $\begin{array}{l}\text { O: Outer surface of inferior ramus of pubis. } \\
\text { I: Pectineal line and proximal part of medial lip of linea aspera of femur. }\end{array}$ & $\begin{array}{l}\text { Add., Flx., } \\
\text { LR.(Asst) }\end{array}$ \\
\hline Adductor Longus & & & $\begin{array}{l}\text { O: Between pubic crest and symphysis. } \\
\text { I: Middle one-third of medial lip of linea aspera of femur. }\end{array}$ & $\begin{array}{l}\text { Add., Flx., } \\
\text { MR.(Asst.) }\end{array}$ \\
\hline Adductor Magnus & & $\begin{array}{l}\text { Tibial division of sciatic } \\
\text { nerve; L2, L3, L4. }\end{array}$ & $\begin{array}{l}\text { O: Inferior ramus of pubis, ramus of ischium, and ischial tuberosity. } \\
\text { I: Medial lip of linea aspera of femur, medial supracondylar line, and adductor tubercle. }\end{array}$ & $\begin{array}{l}\text { Ext.(Asst.), Add., } \\
\text { Flx.(Asst), MR }\end{array}$ \\
\hline Gracilis & & $\begin{array}{l}\text { Obturator nerve; } \\
\text { L2, L3, L4. }\end{array}$ & $\begin{array}{l}\text { O: Inferior ramus of pubis. } \\
\text { I: Medial shaft of tibia via pes anserine tendon. }\end{array}$ & Add., MR.(Asst.) \\
\hline Gluteus Maximus & \multirow{4}{*}{ Gluteal } & $\begin{array}{l}\text { Inferior gluteal nerve; } \\
\quad \mathrm{L} 5, \mathrm{~S} 1, \mathrm{~S} 2 \text {. }\end{array}$ & $\begin{array}{l}\text { O: Posterior iliac crest, sacrum, and sacrotuberous ligament. } \\
\text { I: Greater trochanter of femur, gluteal tuberosity, and lateral tibial condyle via iliotibial band. }\end{array}$ & $\begin{array}{l}\text { Ext., LR., } \\
\text { Ab. (upper fibers), } \\
\text { Add. (lower fibers) }\end{array}$ \\
\hline Gluteus Medius & & \multirow{3}{*}{$\begin{array}{l}\text { Superior gluteal nerve; } \\
\text { L4, L5, S1. }\end{array}$} & $\begin{array}{l}\text { O: External surface of ilium between anterior and posterior gluteal lines. } \\
\text { I: Lateral surface of greater trochanter of femur. }\end{array}$ & $\begin{array}{l}\text { Ab., Asst: (MR., } \\
\text { Flx., Ext., LR.) }\end{array}$ \\
\hline Gluteus Minimus & & & $\begin{array}{l}\text { O: External surface of ilium between anterior and inferior gluteal lines. } \\
\text { I: Anterior border of greater trochanter of femur. }\end{array}$ & $\begin{array}{l}\text { Ab., MR., } \\
\text { Flx.(Asst) }\end{array}$ \\
\hline $\begin{array}{l}\text { Tensor Fasciae } \\
\text { Latae }\end{array}$ & & & $\begin{array}{l}\text { O: Anterolateral lip of iliac crest. } \\
\text { I: Lateral condyle of tibia via iliotibial band. }\end{array}$ & $\begin{array}{l}\text { Flx.(Asst.), } \\
\text { Ab.(Asst.), MR }\end{array}$ \\
\hline Piriformis & \multirow{6}{*}{$\begin{array}{l}\text { Lateral } \\
\text { Rotator }\end{array}$} & Sacral plexus; S1, S2. & O: Anterior surface of sacrum. I: Superior border of greater trochanter of femur. & Ab.(Asst.), LR. \\
\hline Superior Gemellus & & \multirow{2}{*}{ Sacral plexus; L5, S1. } & O: External surface of ischium. I: Medial surface of greater trochanter of femur. & \multirow{2}{*}{$\begin{array}{l}\text { Ab. (Asst), } \\
\text { LR.(Asst.) }\end{array}$} \\
\hline Inferior Gemellus & & & O: Proximal part of ischial tuberosity. I: Medial surface of greater trochanter of femur. & \\
\hline Obturator Internus & & Sacral plexus; L5, S1, S2. & O: Inferior surface of obturator membrane of ischium. I: Medial surface of greater trochanter of femur. & Ab., LR. \\
\hline Obturator Externus & & Obturator nerve; L5, S1. & O: Pubis and ischium, superior and inferior rami. I: Trochanteric fossa of femur. & \multirow{2}{*}{ LR. } \\
\hline Quadratus Femoris & & Sacral plexus; L4 - S2. & O: Lateral part of ischial tuberosity. I: Between greater and lesser trochanters of femur. & \\
\hline Biceps Femoris & \multirow{3}{*}{$\begin{array}{l}\text { Posterior } \\
\text { Femoral } \\
\text { (Hamstring) }\end{array}$} & Sciatic nerve; L5, S1 - S3. & O: Long head: ischial tuberosity, Short head: lateral lip of linea aspera. I: Head of fibula. & Ext., LR.(Asst.) \\
\hline Semimembranosus & & \multirow{2}{*}{$\begin{array}{l}\text { Tibial division of sciatic } \\
\text { nerve; L5, S1, S2. }\end{array}$} & O: Ischial tuberosity. I: Posteromedial portion of medial tibial condyle. & \multirow{2}{*}{ Ext., MR.(Asst.) } \\
\hline Semitendinosus & & & O: Ischial tuberosity. I: Medial tibial shaft via pes anserine tendon. & \\
\hline
\end{tabular}


Table 2: Muscles acting on lower extremity Knee Joint [23,30-32]

\begin{tabular}{|c|c|c|c|c|}
\hline Muscles (Knee joint) & Group & Innervation & Attachments & Functions \\
\hline Rectus Femoris & \multirow{4}{*}{ Quadriceps } & \multirow{4}{*}{$\begin{array}{l}\text { Femoral nerve; } \\
\text { L2 - L4. }\end{array}$} & $\begin{array}{l}\text { O: Anterior inferior iliac spine } \\
\text { (AIIS). } \\
\text { I: Tibial tuberosity via patellar } \\
\text { tendon. }\end{array}$ & \multirow{4}{*}{ Ext. } \\
\hline Vastus Lateralis & & & $\begin{array}{l}\text { O: Greater trochanter of femur, } \\
\text { gluteal tuberosity, and proximal, } \\
\text { lateral lip of linea aspera. } \\
\text { I: Tibial tuberosity via patellar } \\
\text { tendon. }\end{array}$ & \\
\hline Vastus Medialis & & & $\begin{array}{l}\text { O: Intertrochanteric line and } \\
\text { medial lip of linea aspera of } \\
\text { femur. } \\
\text { I: Tibial tuberosity via patellar } \\
\text { tendon. }\end{array}$ & \\
\hline Vastus Intermedius & & & $\begin{array}{l}\text { O: Proximal two-thirds of anterior } \\
\text { shaft of femur. } \\
\text { I: Tibial tuberosity via patellar } \\
\text { tendon. }\end{array}$ & \\
\hline Sartorius & $\begin{array}{l}\text { Anterior } \\
\text { Femoral }\end{array}$ & $\begin{array}{l}\text { Femoral nerve; } \\
\text { L2 - L3 }\end{array}$ & $\begin{array}{l}\text { O: Anterior superior iliac spine } \\
\text { (ASIS). } \\
\text { I: Medial shaft of tibia via pes } \\
\text { anserine tendon. }\end{array}$ & $\begin{array}{l}\text { Flx. (Asst.), MR. } \\
\quad \text { (Pronation) }\end{array}$ \\
\hline Biceps Femoris & \multirow{3}{*}{$\begin{array}{l}\text { Posterior } \\
\text { Femoral } \\
\text { (Hamstring) }\end{array}$} & $\begin{array}{l}\text { Tibial division (long } \\
\text { head) and common } \\
\text { peroneal division } \\
\text { (short head) of sciatic } \\
\text { nerve; } \\
\text { L5, S1 - S3. }\end{array}$ & $\begin{array}{l}\text { O: Long head: ischial tuberosity; } \\
\text { Short head: lateral lip of linea } \\
\text { aspera. } \\
\text { I: Head of fibula. }\end{array}$ & $\begin{array}{c}\text { Flx., LR. } \\
\text { (Supinaiton) }\end{array}$ \\
\hline Semimembranosus & & Tibial division of & $\begin{array}{l}\text { O: Ischial tuberosity. } \\
\text { I: Posteromedial portion of medial } \\
\text { tibial condyle. }\end{array}$ & \multirow{2}{*}{ Flx., MR. (Pronation) } \\
\hline Semitendinosus & & $\mathrm{L} 5$ - S2. & $\begin{array}{l}\text { O: Ischial tuberosity. } \\
\text { I: Medial tibial shaft via pes } \\
\text { anserine tendon. }\end{array}$ & \\
\hline Popliteus & Lateral Rotator & $\begin{array}{l}\text { Tibial nerve; } \\
\text { L4 - S3 }\end{array}$ & $\begin{array}{l}\text { O: Lateral femoral condyle. } \\
\text { I: Proximal posterior surface of } \\
\text { tibia. }\end{array}$ & \multirow{2}{*}{$\begin{array}{l}\text { Flx. (Asst), MR. } \\
\text { (Pronation) }\end{array}$} \\
\hline Gracilis & Adductor & $\begin{array}{l}\text { Obturator nerve; } \\
\text { L2 - L4. }\end{array}$ & $\begin{array}{l}\text { O: Inferior ramus of pubis. } \\
\text { I: Medial shaft of tibia via pes } \\
\text { anserine tendon. }\end{array}$ & \\
\hline
\end{tabular}

O: Medial head: posterior surface of medial femoral condyle;

Gastrocnemius

Lateral head: posterior surface of lateral femoral condyle.

Flx. (Asst.)

I: Posterior surface of calcaneus

$\begin{array}{lr}\text { Triceps surae } & \text { Tibial nerve; } \\ \mathrm{S} 1-\mathrm{S} 2 .\end{array}$ via Achilles tendon.

O: Distal part of latera

supracondylar line of femur.

I: Posterior surface of calcaneus

via Achilles tendon.

*O: Origin. *I: Insertion. *Flx.: Flexion. *Ext.: Extension. *Ab.: Abduction. *Add.: Adduction. *MR: Medial Rotation. *LR: Lateral Rotation. *Asst.: Assisting Muscle. 
Table 3: Muscles acting on lower extremity Ankle Joint [26,30-32]

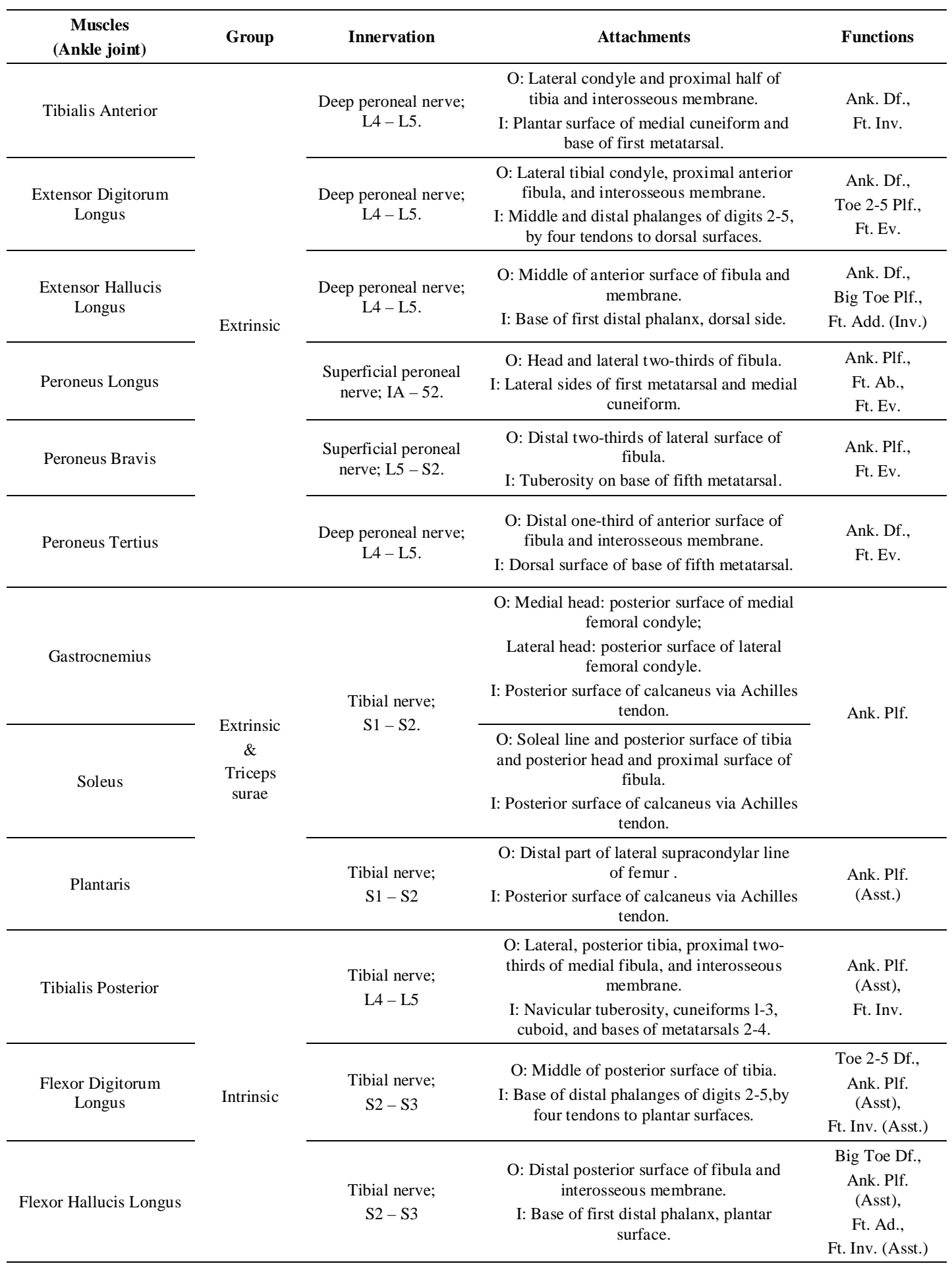

*O: Origin. *I: Insertion. *Ank..: Ankle. *Df.: Dirsiflexion. *Plf..: Plantarflexion. *Add.: Adduction. *Ab.: Abduction. *Inv.: Inversion. *Ev.: Eversion. *Ft.: Foot. *Asst.: Assisting Muscle.

Movements of joints occur along any of three section planes of human body, Sagittal plane (Lateral plane), Frontal plane (Coronal plane), and Transverse plane (Axial plane) $[28,33]$. Each of these three planes has corresponding axis around which a particular 
movement occurs. Movements, Flexion and Extension (front-back) occur on Sagittal plane along Frontal axis, Abduction and Adduction (side-side) occur on Frontal plane along Sagittal axis, and rotational movements, Lateral rotation and Medial rotation, occur on Transverse plane along Longitudinal axis. Muscles that are involved in particular movements of limbs can be grouped together to identify and monitor performances of affected muscles during rehabilitation or therapy. Muscle groups are presented in Table 4, Table 5, and Table 6, according to the movements of the lower extremity of a human body.

Table 4: Hip joint movements and muscle groups [23,32]

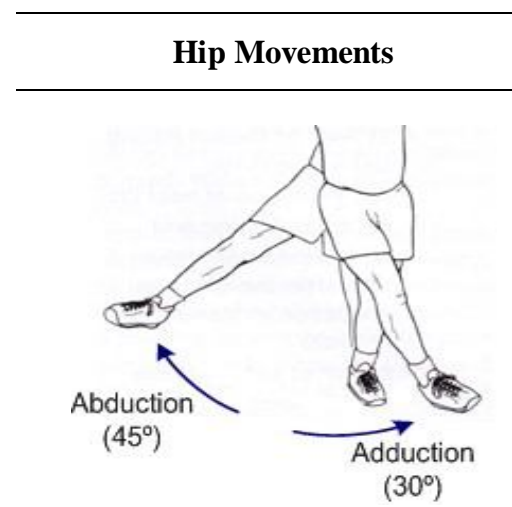

\begin{tabular}{ll} 
& \\
\hline 1. & \multicolumn{1}{c}{ Abductor } \\
2. & Sartorius \\
3. & Pensor fascia latae \\
4. & Giuteus maximus \\
& (upper fibers) \\
5. & Gluteus medius \\
6. & Gluteus minimus \\
7. & Gemellus superior \\
8. & Gemellus inferior \\
9. & Obturator internus
\end{tabular}

Muscle groups

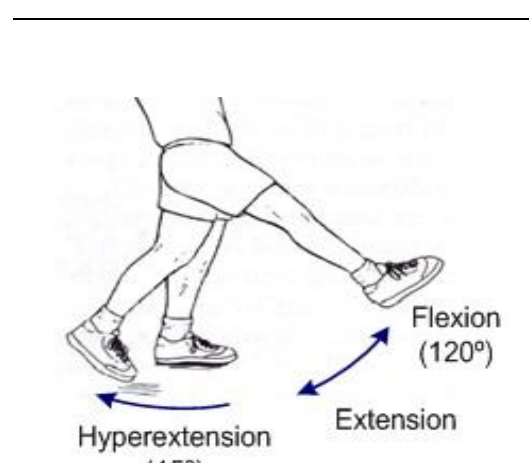

$\left(15^{\circ}\right)$

\section{Extensor}

1. Adductor magnus (posterior fibers)

2. Gluteus maximus

3. Gluteus medius (posterior fibers)

4. Biceps femoris (long head)

5. Semimembranosus

6. Semitendinosus

Adductor

1. Pectineus

2. Adductor brevis

3. Adductor longus

4. Gracilis

5. Adductor magnus

6. Gluteus maximus (lower fibers)

\section{Flexor}

1. Psoas

2. Iliacus

3. Sartorius

4. Tensor fascia latae

5. Rectus femoris

6. Pectineus

7. Adductor brevis

8. Adductor longus

9. Adductor magnus (anterior fibers)

10. Gluteus medius (anterior fibers)

11. Gluteus minimus

\section{Lateral Rotator}

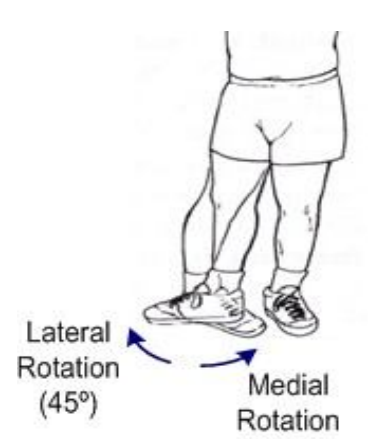

1. Psoas

2. Iliacus

3. Sartorius

4. Adductor brevis

5. Gluteus maximus

6. Gluteus medius (posterior fibers)

7. Piriformis

8. Gemellus superior

9. Gemellus inferior

10. Obturator internus

11. Obturator extemus

12. Quadratus femoris

13. Biceps femoris (long head)

\section{Medial Rotator}

1. Tensor fascia latae

2. Gluteus medius (anterior fibers)

3. Gluteus minimus

4. Semimembranosus

5. Semitendinosus 
Table 5: Knee joint movements and muscle groups [23,32]

\begin{tabular}{|c|c|c|}
\hline Knee Movements & Mus & groups \\
\hline$\underset{\left(135^{\circ}\right)}{\text { Flexion }}$ & \begin{tabular}{ll} 
& \multicolumn{1}{c}{ Extensor } \\
1. & Rectus femoris \\
2. & Vastus lateralis \\
3. & Vastus intermedius \\
4. & Vastus medialis
\end{tabular} & \begin{tabular}{ll} 
& \multicolumn{1}{c}{ Flexor } \\
1. & Sartorius \\
2. & Gracilis \\
3. & Biceps femoris \\
4. & Semimembranosus \\
5. & Semitendinosus \\
6. & Plantaris \\
7. & Popliteus \\
8. & Gastrocnemius
\end{tabular} \\
\hline Knee Lateral & $\begin{array}{l}\text { Lateral Rotator } \\
\text { 1. Biceps femoris }\end{array}$ & $\begin{array}{ll} & \text { Medial Rotator } \\
\text { 1. } & \text { Gracilis } \\
\text { 2. } & \text { Sartorius } \\
\text { 3. } & \text { Semimembranosus } \\
\text { 4. } & \text { Semitendinosus } \\
\text { 5. } & \text { Popliteus }\end{array}$ \\
\hline
\end{tabular}

Table 6: Ankle and foot movements and muscle groups [26,32]

\begin{tabular}{|c|c|c|}
\hline Foot Movements & Musc & groups \\
\hline$\sum_{\substack{\text { Plantar flexion } \\
\left(50^{\circ}\right)}}$ & $\begin{array}{ll} & \text { Dorsiflexor (Flexor) } \\
\text { 1. } & \text { Tibialis anterior } \\
\text { 2. } & \text { Extensor digitorum longus } \\
\text { 3. } & \text { Extensor hallucis longus } \\
\text { 4. } & \text { Peroneus tertius }\end{array}$ & $\begin{array}{ll} & \text { Plantar flexor (Extensor) } \\
\text { 1. } & \text { Gastrocnemius } \\
\text { 2. } & \text { Soleus } \\
\text { 3. } & \text { Plantaris } \\
\text { 4. } & \text { Peroneus longus } \\
\text { 5. } & \text { Peroneus brevis } \\
\text { 6. } & \text { Tibialis posterior } \\
\text { 7. } & \text { Flexor digitorum longus } \\
\text { 8. } & \text { Flexor hallucis longus }\end{array}$ \\
\hline$\underset{\text { Inversion }}{\left(45^{\circ}-80^{\circ}\right)} \underset{\substack{\text { Eversion } \\
\left(15^{\circ}-30^{\circ}\right)}}{(1)}$ & \begin{tabular}{ll} 
& \multicolumn{1}{c}{ Foot invertor } \\
1. & Tibialis anterior \\
2. & Extensor hallucis longus \\
3. & Tibialis posterior \\
4. & Flexor digitorum longus \\
5. & Flexor hallucis longus
\end{tabular} & \begin{tabular}{ll} 
& \multicolumn{1}{c}{ Foot evertor } \\
1. & Extensor digitorum longus \\
2. & Peroneus longus \\
3. & Peroneus brevis \\
4. & Peroneus tertius
\end{tabular} \\
\hline $\begin{array}{c}\text { Toe extension } \\
\left(70^{\circ}-90^{\circ}\right)\end{array}$ & $\begin{array}{l}\text { Toe extensor (Plantar flx.) } \\
\text { 1. Extensor digitorum longus } \\
(2-5) \\
\text { 2. Extensor hallucis longus (1) }\end{array}$ & $\begin{array}{ll} & \text { Toe flexor (Dorsiflx.) } \\
\text { 1. } & \text { Flexor digitorum longus } \\
\text { 2. } & (2-5) \\
\text { 3. } & \text { Flexor hallucis longus (1) }\end{array}$ \\
\hline
\end{tabular}


Intrafusal fiber is a special muscle fiber of muscle spindle which is surrounded by a coil of sensory nerve endings, 'Gamma motor neuron' and 'Afferent fibers'. Muscle spindles are special nerves distributed in muscles and tendons that monitor stimuli regarding changes of position, movement, and magnitude of stretch of muscle tissues [27]. If any external force is applied, 'Extrafusal fibers' of muscle spindle acknowledge 'Alpha motor neuron' to adjust length of muscles in order to protect muscle fiber from damage. This reaction is known as Myotatic Reflex. On the other hand, tension of muscle spindle is adapted by 'Gamma motor neurons' to manage length monitoring function [27,34]. In terms of therapy, it is important to consider that a fast or strong force or stretch that cross a certain limit may cause potential damage of tissues [27,34]. Force-velocity relationship of muscle shows inverse characteristics as increment of external force will decrease motion velocity $[35,36]$. So, it is important to consider and analyze these biological functions and reactions in designing robot assisted rehabilitation systems.

\section{CONCLUSION}

The main focus of lower limbs rehabilitation is to maintain normal mobility of lower extremity joints by providing external force in harmony to ensure repetitive and persistent movement actions within the range of musculoskeletal motion. Therefore, the lower extremity maintains its normal functions instead of muscles being shrunk and will improve muscle performance as well as the nervous system. As an automated rehabilitation system should provide better facility to do exercise without any risk of accident or secondary injury, it is very important to study human musculoskeletal structure. Considering this point, the review presents a basic overview on musculoskeletal structure of human lower limbs by characterizing and classifying skeletal and muscular system based on various types of functionalities, movements, and joint architecture.

\section{ACKNOWLEDGEMENT}

The authors would like to express their gratitude to the Ministry of Education (MOE), Malaysia for funding the project through the Fundamental Research Grant Scheme (FRGS).

\section{REFERENCES}

[1] Venketasubramanian N. (1998) The epidemiology of stroke in ASEAN countries - A Review. Neurol J. Southeast Asia, 3:9-14.

[2] Glamcevski MT, Tan CT. (2000) Prevalence of post-stroke depression, a Malaysian study. Neurol J. Southeast Asia, 5:51-53.

[3] Tan KS, Tan CT, Churilov L, Mackay M, Donnan GA. (2010) Ischaemic stroke in young adults: A comparative study between Malaysia and Australia. Neurology Asia, 15(1):1- 9.

[4] Nazifah SN, Azmi IK, Hamidon BB, Looi I, Zariah AA, Hanip MR. (2012) National Stroke Registry (NSR): Terengganu and Seberang Jaya Experience. Med. J. Malaysia, 67(3):302304.

[5] Johnson MJ. (2006) Recent trends in robot-assisted therapy environments to improve real-life functional performance after stroke. J. NeuroEngin. Rehab., 3(29):1-6.

[6] Hesse S, Mehrholz J, Werner C. (2008) Robot-assisted upper and lower limb rehabilitation after stroke: walking and arm/hand function. MEDICINE, Dtsch Arztebl Int., 105(18):330336.

[7] Akhtaruzzaman M, Shafie AA, Khan MR. Electro-goniometric system; an instrumentation to capture knee movements for forward walking. The $10^{\text {th }}$ Asian Control Conference 2015 (ASCC 2015), May 31 2015-June 3 2015, Kota Kinabalu, Malaysia, pp. 1-4. 
[8] Hidler J, Nichols D, Pelliccio M, Brady K. (2005) Advances in the understanding and treatment of stroke impairment using robotic devices. Topics in Stroke Rehabilitation, Thomas Land Publishers, Inc., 12(2):22-35.

[9] Capó-Lugo CE, Mullens CH, Brown DA. (2012) Maximum walking speeds obtained using treadmill and overground robot system in persons with post-stroke hemiplegia. J. NeuroEng. Rehab., 9(1):1-14.

[10] Akhtaruzzaman M, Shafie AA, Khan MR. Gait Analysis: Systems, Technologies, and Importance. Journal of Mechanics in Medicine and Biology, World Scientific Publishing Company, 16(7), Accepted on Dec. 20, 2015.

[11] Sartori M, Lloyd DG, Reggiani M, Pagello E. (2009) A stiff tendon neuromusculoskeletal model of the knee. IEEE Workshop on Advanced Robotics and its Social Impacts, Tokyo, Japan, November 23-25, pp. 132-138.

[12] Sartori M, Lloyd DG, Reggiani M, Pagello E. (2010) Fast operation of anatomical and stiff tendon neuromuscular models in EMG-driven modeling. IEEE Int. Conf. on Robotics and Automation (ICRA), pp. 2228-2234.

[13] Akhtaruzzaman M, Shafie AA, Khan MR. (2016) Automated Threshold Detection for Object Segmentation in Colour Image. ARPN Journal of Engineering and Applied Sciences, Asian Research Publishing Network (ARPN), Vol. 11, No. 6, pp. 4100-4104.

[14] Akhtaruzzaman M, Shafie AA, Khan MR. (2016) Representation of Human Gait Trajectory through Temporospatial Image Modelling. ARPN Journal of Engineering and Applied Sciences, Asian Research Publishing Network (ARPN), Vol. 11, No. 6, pp. 4105-4110.

[15] Sartori M, Reggiani M, Lloyd DG, Pagello E. (2011) A neuromusculoskeletal model of the human lower limb: Towards EMG-driven actuation of multiple joints in powered orthoses. IEEE Int. Conf. Rehabilitation Robotics, ETH Zurich Science City, Switzerland, June 29 July 1, pp. 706-714

[16] Oatis CA. (2009) Kinesiology: The Mechanics \& Pathomechanics of Human Movement, Second Edition. Wolters Kluwer Health/Lippincott, Williams \& Wilkins.

[17] Pennestrı E, Stefanelli R, Valentini PP, Vita L. (2007) Virtual musculo-skeletal model for the biomechanical analysis of the upper limb. J. Biomechanics, 40:1350-1361.

[18] Reid CRD. (2009) Occupational lower extremity risk assessment modeling. Ph.D. Thesis, University of Central Florida, Orlando, Florida, USA.

[19] Arnoczky SP, McDevitt CA. (2000) The Meniscus: Structure, Function, Repair, and Replacement. Orthopaedic Basic Science: Biology and Biomechanics of the Musculoskeletal System, 2nd Edition. Editors: Joseph A. Buckwalter, Thomas A. Einhorn, Sheldon R. Simon. American Academy of Orthopaedic Surgeons, pp. 532-545.

[20] Woo SLY, An KN, Frank CB, Livesay GA, Ma CB, Zeminski J, Wayne JS, Myers BS. (2000) Anatomy, Biology, and Biomechanics of Tendon and Ligament. Orthopaedic Basic Science: Biology and Biomechanics of the Musculoskeletal System, 2nd Edition. Editors: Joseph A. Buckwalter, Thomas A. Einhorn, Sheldon R. Simon. American Academy of Orthopaedic Surgeons, pp. 582- 616.

[21] Garrett WE, and Best TM. (2000) Anatomy, Physiology, and Mechanics of Skeletal Muscle. Orthopaedic Basic Science: Biology and Biomechanics of the Musculoskeletal System, 2nd Edition. Editors: Joseph A. Buckwalter, Thomas A. Einhorn, Sheldon R. Simon. American Academy of Orthopaedic Surgeons, pp. 684-716.

[22] Cael C. (2010) Functional Anatomy: Musculoskeletal Anatomy, Kinesiology, and Palpation for Manual Therapists, Chapter 2, Osteology and Arthrology. Wolters Kluwer Health/Lippincott, Williams \& Wilkins, pp. 26-48.

[23] Cael C. (2010) Functional Anatomy: Musculoskeletal Anatomy, Kinesiology, and Palpation for Manual Therapists, Chapter 8, Pelvis, Thigh and Knee. Wolters Kluwer Health/Lippincott, Williams \& Wilkins, pp. 307-369.

[24] Jung HJ, Fisher M B, Woo SLY. (2009) Review: Role of biomechanics in the understanding of normal, injured, and healing ligaments and tendons. Sports Medicine, Arthroscopy, Rehabilitation, Therapy \& Technology, 1(9):1-17. 
[25] Recklies AD, Poole AR, Banerjee S, Bogoch E, Batista JD, Evans CH, Firestein GS, Frank CB, Karp DR, Mort JS, Marks NO, Varga J, Berg WVD, Zhang Y. (2010) Pathophysiologic Aspects of Inflammation in Diarthrodial Joints. Orthopaedic Basic Science: Biology and Biomechanics of the Musculoskeletal System, 2nd Edition. Editors: Joseph A. Buckwalter, Thomas A. Einhorn, Sheldon R. Simon. American Academy of Orthopaedic Surgeons, pp. 489-530.

[26] Cael C. (2010) Functional Anatomy: Musculoskeletal Anatomy, Kinesiology, and Palpation for Manual Therapists, Chapter 9: Leg, Ankle, and Foot. Wolters Kluwer Health/Lippincott, Williams \& Wilkins, pp. 371-421.

[27] Cael C. (2010) Functional Anatomy: Musculoskeletal Anatomy, Kinesiology, and Palpation for Manual Therapists, Chapter 3: Myology. Wolters Kluwer Health/Lippincott, Williams \& Wilkins, pp. 49-73.

[28] Neumann DA. (2010) Kinesiology of the Musculoskeletal System: Foundations for Rehabilitation, Second Edition. Mosby, Elsevier.

[29] Seeley RR, Stephens TD, Tate P. (2004) Anatomy and Physiology (6th Edition), Chapter 10: Muscular System Gross Anatomy. McGraw-Hill Science Engineering, pp. 313-362.

[30] Martini F, Timmons M, Tallitsch R. (2005) Human Anatomy (5th Edition), Chapter 11: The Muscular System, The Appendicular Musculature. Benjamin Cummings, pp. 284-326.

[31] Thibodeau GA, Patton KT. (2007) Anatomy and Physiology (6th Edition), Unit II, Support and Movement, Chapter 10: Anatomy of the Muscular System. Mosby Elsevier, pp. 347-393.

[32] Hamill J, Knutzen KM. (2009) Biomechanical Basis of Human Movement (3rd Edition), Section II: Functional Anatomy, Chapter 6: Functional Anatomy of the Lower Extremity. Wolters Kluwer Health/Lippincott, Williams \& Wilkins, pp. 187-257.

[33] Akhtaruzzaman M, Shafie AA. (2011) An attempt to develop a biped intelligent machine BIM-UIA. 4th International Conference on Mechatronics (ICOM'11), 17-19 May, Kuala Lumpur, Malaysia.

[34] Hamill J, Knutzen KM. (2009) Biomechanical Basis of Human Movement (3rd Edition), Section I: Functions of Human Movement, Chapter 4: Neurological Considerations for Movement. Wolters Kluwer Health/Lippincott, Williams \& Wilkins, pp. 105-135.

[35] Visser JJ, Hoogkamer JE, Bobbert MF, Huijing PA. (1990) Length and moment arm of human leg muscles as a function of knee and hip-joint angles. Eur. J. App. Phys., 61:453- 460.

[36] Dzahir MAM, Yamamoto S. (2014) Recent trends in lower-limb robotic rehabilitation orthosis: Control scheme and strategy for pneumatic muscle actuated gait trainers. Robotics, 3:120-148. doi:10.3390/robotics3020120. 